\title{
The Politics of Sport in National Resilience Perspective
}

\author{
Noorochmat Isdaryanto \\ \{noorochmatx@yahoo.co.id\} \\ Universitas Negeri Semarang, Indonesia
}

\begin{abstract}
The National Resilience Study is always related to the discussion of national character with human existence as its center. In humans, the mental pole becomes the "regnant nexus", while the physical pole becomes the "subservient", this raises the question of whether mental education takes precedence over physical education in the context of National Defense. This paper aims to examine the politics of sport in Law No. 3 Year 2005 about National Sports System as an effort to create civic fitness to strengthen the Indonesian National Resilience. Sports is expanded from an individual activity into a citizen activity. This expansion is expected to develop the physical, spiritual, and social potential of citizens. Civic fitness concepts and ideas are the basis for structuring sports regulations derived from physical education to serve as preliminary lessons in Indonesian Civil Defense Program. While the competence of citizens in certain sports, such as shooting, archery, throwing, self-defense, can be accelerated as the ability of citizenship to strengthen Indonesian national resilience.
\end{abstract}

Keywords: National Resilience, National Sports System, The Politics of Sport, Civic Fitness.

\section{Introduction}

The National Resilience Study is associated with the discussion of national character in many ways. This matter cannot be separated from the view that says humans are more to a mental entity than a physical entity. A. Whitehead stated that the difference between humans and other material things is in the physical pole and mental pole position. For common material things, the physical pole is the core (regnant nexus) and the mental pole is it's subservient. Meanwhile, in humans, mental poles are the core and physical poles are devotees (subservient). In real life, such understanding intrigues the statement that says the spiritual (mental) things are considered more important than physical things. Therefore, discussions about physical things are not very common to many people, when compared to spiritual things. The consequence is the development of physical studies become less desirable, especially its correlation with the idea of National Resilience.

However, is there no connection between physical things and the ideas or the spirit of National Resilience? This question is very important, considering that in practice, the issue of National Resilience or which was later revealed to be the idea of Indonesian Civil Defense could never be separated from the presence of the National Police and the TNI as a whole. As we all know, the idea of National Resilience covers two core areas, namely defense and security issues. The issue of defense is related to threats originating from outside the country and then implemented by the Indonesian National Army. Meanwhile, security issues are related to conditions in the country which are then handled by the Police of the Republic of Indonesia. This shows that the idea of National Resilience could be seen from the State Defence concept 
depends on the physical structures. It can be said that the need to develop physical matters is necessary for National Resilience ideas.

The National Defense System which tends to require physical matters needs to be explained in the form of specific activities so that they can be formulated properly. The main abilities that are considered proper to this system so far have always been related to military skills. This fact should be viewed through a new discussion that character education is not something that should be explained in mere concepts. Basic military capabilities such as shooting, swimming, running, etc. are more needed in national defense actions. The purpose of this statement is certainly not to downplay or override human intellectual capabilities. However, this statement shows that the development of physical activities is incredibly crucial in sustaining the National Resilience system.

These physical activities, in general, can be found in all kinds of sports. Sports branches such as martial arts, archery, swimming, shooting, horseback riding, are types of sports that would be accommodated by the state directly. In short, the heavy sports above got special attention from the government, so they experienced a good system and management. Through this good arrangement, attention or good management also appears. It has been considered common when athletes who have great achievements in heavy sports above are offered to become military or police officers. As if, ordinary people with the average abilities will not have fair attention from the government. However, is that true? Is it just those sports that can affect people's social life?

This paper was written to uncover the connection between sports and politics. The trigger for this motive is quite simple; the special treatment given by the government only to certain types of sports. The most reasonable cause is located in the potential possessed by that sport. However, if explored in more depth, the problem is in the potential chaos that could have occurred if those certain sports were carried out by everyone. The appropriate term to describe this situation is, a type of sport will get special attention if it can be used for combat. The problem that has been found temporarily is that almost all sports involving physical skills can actually be used for combat. Then, why do these regulations and special treatments still survive? In fact, with a better arrangement, all sports that involve physical activity can be a good shield for the National Resilience system in Indonesia.

\section{Research Method}

Sport has existed since ancient times, even if associated with the game, sport is one of the many things that have emerged along with the appearance of humans. As is believed in Hinduism, Lord Shiva was the earliest God who created all the games played by humans. Shiva created the game so that humans can understand how the universe works and improve their abilities as a human being. Sports as an advanced model of a game then also adopt this function, so that in its journey someone involved in sports activities will have special skills. Therefore, before entering into the discussion of the relationship between sports and politics, it is better to know the definition of sports first.

\subsection{Sports definitions in general}

The Cambridge Dictionary states that sport is a game, competition, or activity that requires physical effort and the ability to play or be carried out based on rules, which are intended for 
pleasure and / or as a job. Sports are also defined as all types of physical activity carried out by people to stay healthy or to get pleasure [1]. This definition is the definition most commonly used to explain the meaning of sports. Through this understanding, it can be concluded that sports are related to physical activities, certain abilities, rules, and then the function to be happy or as a job/career. This simple understanding of sport has been able to show that sport is a serious activity requiring special skills, rules, and specific goals. The definition from the Cambridge Dictionary above can be used to see the importance of the position of the sport. Meanwhile, for some people, the sport function is attached only as an activity to fill free time. Sometimes even sports are carried out under conditions that are not optimal so that instead of being able to achieve the ideal function, sports like this cause accidents. Thus, it can be said that exercise will only achieve optimal function if it is carried out in its ideal form. Likewise, sport is something that must be agreed upon by the rules because by doing so, there are good and great conditions that can be obtained from it.

A muscle activity that is exhibited by an athlete as much as possible. Meanwhile UNESCO sport, explained that sport is a physical activity in the form of a game to fight the elements of nature, others, and also to yourself [2]. This view broadens the definition previously presented, that sport basically has the enthusiasm to be exhibited to overcome existing challenges. Sports through this understanding manifests itself as an effort to fight something. Thus, it can be said that sport does have a purpose to show power over something. Winners, when they won a match, have given the best competition possible. After that, the outcome for the winner, that she or he will get recognition and prizes, even get certain power.

The above understanding unmasked about sports which so far may rarely be discussed in serious studies. Professional athletes who have worldwide have an influence that can defeat the influence of a scholar. Great athletes such as Muhammad Ali, Michael Jordan, Leo Messi, Ronaldo, and so on can give influence on many people. Thus, the view that sport only considered a as hobby or a pleasure time-filler activity is unfit. It is this difference in perspective which also makes the development of countries different. Call China, it has athletes who are deliberately trained from childhood, to win world championships, such as Olympic and other world sporting events. Likewise, other major countries such as the United States, Russia, and Korea.

\subsection{Definitions of Sports in the Indonesian Perspective}

As a comparison, it would be better to try to see the definition or understanding given by the Indonesian government for sports. Indonesian sports system based on Law No. 3 of 2005 concerning the National Sports System. Law No. 3 of 2005 is a very important milestone to look and analyse the position and condition of the national sports system. The first point that can be taken is about the consideration related to the efforts in educating the national life through sports. This action can be considered as an effort to improve the quality of Indonesian people life, physically, spiritually, and socially in realizing an advanced, just, prosperous, prosperous, and democratic society based on Pancasila and the constitution of the Republic of Indonesia (UUD 1945). Next point will explain that the development and of national sports are able to guarantee equitable access to sports, health and fitness improvement, improvement of achievement, and sports management that is able to deal with challenges and demands for national and global life change [3].

Meanwhile, the important aspects in national sports activities or systems can be found in Chapter I of Law No. 3 of 2005, especially in paragraphs 1 to 15 . The following is a copy of Chapter I of Law No. 3 of 2015, Law No. 3/2005 concerning the National Sports System above 
shows the vital and strategic position that has been charged to national sports in Indonesia. At least there are a number of important points revealed in the Law above, namely:

1. National sports system includes aspects of planning, systematic, integrated, and sustainable. This system also involves the arrangement, education, training, management, guidance, development, and supervision,

2. Sport based on its function is divided into three types, namely: educational sports, recreational sports, performance sports,

3. Sport is generally divided into two types, namely: Amateur sports and professional sports.

The temporary conclusions can be drawn from the points contained in Law No. 3 of 2005 is a sport that is desired by the Indonesian government is not something simple. Planning for the national sports system has been arranged in such a way and involves all aspects needed for the progress of the nation. Hence, sport should not only be discussed as something related to physical development, but also spiritual and social community. The sport's position they should be placed equal to other strategic developments such as religion, politics, social and other fields. Moreover, sport through its regulatory basis is also very feasible to collaborate with other strategic fields.

\section{Result and Discussion}

\subsection{Relation Bertween Sports and Political in National Identity Viewpoint}

The existence of Law No. 3 of 2005 shows that sport is not only physical activities to fix the human body problems. The consideration given in assisting the National Sports System clearly refers to the constitution of the Republic of Indonesia (UUD 1945). Everything that is referred to the constitution directly, by taking preference on one of the four main ideas of the Preamble to the UUD 1945, can be considered as a state political activity. Indirectly, the mention of the basic regulation that refers to the State Constitution shows a clear relationship between sports and politics. Although in the implementation, this kind of idea has not been done massively. Although we can believe that between State Politics and sports there are actually quite complex relationships. This relationship based on the purpose of both ideas to develop Indonesia in the future.

According to Anirotul Qoriah the main value of olimpism is the sport separation from politics, but this pretension is not fully achieved in practice. This is caused by the athlete's spirit when come to competition. An athlete's spirit cannot be separated from his nationality and as a good citizen. Even, large-scale sports competitions have been considered as a battle that involving the states, athletes, and citizens of that country. For example, the audience or supporters carries their country flags as a sign to the opposing party that they are on their country's side. This action for sure is a political activity and also political campaign This is certainly conceptually opposed to what athletes should believe. (Qoriah, 2015)[5].

The main point conveyed by Qoriah is about the inseparable political aspects or nationalism in sports activities at this time. This point also triggers studies on sports nationalism. However, the study of sports nationalism has not been studied or developed so much in Indonesia. The reason could be laid on the development of national sports with the so many stumbling cases in its people. Meanwhile, practically sports nationalism can greatly influence a country's politics. Likewise, sport and all its attributes and events have had a significant influence on the country. 
As a result, the positive aspects that sports have in some countries have benefited. Especially, the minor activities of sport these days have become one of the effective ways for the nations of the world in terms of forming community.

Alan Bairner (2001) conveys important points that have good relation to global sports activities. Bairner believes that sports at this time have succeeded in reconstructing and reproducing human identity. The relationship found by Bairner between Nationalism and Sports is indeed unstable, being up in some countries but also decreasing in some other countries. Global sports events which is precisely develop one's national identity. Activities such as bringing the country's flag to the stadium and wearing a shirt (jersey) with national identity are common activies nowadays. The sense of nationalism then came back to life through this kind of activity [6].

An athlete will experience an increase in enthusiasm for achievement and provide the best for his nation. This can be analyzed as well as if someone has the support of his group in a representation. There are two things that flare up in his chest, first the desire to give the best, second, to give everything as wanted by the group. Even further it is said that when someone feels that his struggle is to show devotion, then there is actually a potential form of burden in him. This burden may make it stronger, but it can also become a source of burden thereby limiting potential [7].

Nationalism in sports battles then becomes a package that seems inseparable. An athlete is someone who must also possess the values and spirit of nationalism. The value that sometime arises as a inability to not fighting as well as possible for his country. The pressure being able to make a winning of the game. This view for sure, is good for systems dealing with national integration, such as the National Resilience system or State Defending action (civic defence). At least the premise that arises is that the national defense system could plant the seeds of nationalism through sports. We can see, when Indonesian citizens cannot use badminton rackets, they are embarrassed because their country has the best quality of badminton players in the world. As Brazilian would feel the same becuse their pride laid on soccer.

\subsection{The Politics of Sport and State Resilience Systems}

The national defense system is basically universal or holistic, so that all national resources will be involved. This system must be prepared early by the government and carried out in a total, integrated, directed and sustainable manner to uphold the country's sovereignty, safeguard the territorial integrity and also safety of all nations from any kind of threats. In other words, the relationship between sports and the National Defense System can actually be explained politically. This statement was aided by the elaboration in the previous discussion, that nationalism could be developed through sports, even more effectively than other methods. When a sporting event is held, the community will reveal its national identity proudly. The political culture that emerged in the community would be more easily developed at a personal level. Thus, developing the idea of sports politics in shaping the mentality or character of citizens for the sake of national defense will be easier.

In practice, the national goal on national sports is to create civic fitness. This fitness will indeed also be involved in competence, for example the initial ability in defending the country. The problem is that this kind of sports competence, which is related to citizens, has not been specifically categorized as a national resource. Meanwhile, potentially, the existing human resources in citizens to defend the country is something most important. An effort is needed to implicate all the points contained in the National Sports System Law in a more practical form. 
The state and the government must find a holistic concept, till be able to introduce the politics of sport as a part of the national resilience system. This can be approached as a new cultural process is started by a community. Andri Azis Putra (2017) calls this as an effort to communicate something through universal values which are also historical in nature. Putra referred his view to Bakker's opinion which states that the cultural process is basically a human creation that is free, superorganic, and puliform. These things can be separated from the shape of the whole process [8]. Thus, the sports political campaign needed to support the national resilience system and has to be based on the cultural needs of the community. In this way then, sport will begin to be understood as something comprehensive. The new pattern must be recognized that the sports culture in Indonesian people vies are still partial. Sport is not considered as something directly related to strategic matters of state. It is necessary to re-create sports values to have direct contact with politics, with the ideal goal of being a form of participation in the national defense system building.

The need for political sports culture is mandated by the constitution. Bambang Darmono (2010) revealed that National Security idealims is written in the constitution, namely "protecting the entire Indonesian nation and the whole of Indonesian blood". Bambang then stated that this idealism included several points, namely 1) protection of citizens in general terms and also related to human rights, 2) protection of society, 3) and protection of the state. These three points actually do show that the national security system is comprehensive. Bambang then continued that although it had taken the universal form of the idea of national security, National Security for the Nation and the State of Indonesia must still pay attention to the historical experience of the Indonesian Nation. Furthermore, Darmono revealed that the intended National Security was no longer only a defense controlled through military force alone. However, the National Security to be addressed also relates to the calm or peace felt by everyone [9].

An important point conveyed by Darmono is that National Security or National Defense must be basic and cultural in nature. This is necessary so that the form of security in question is not a solution to military methods that tend to be violent. However, the National Security that must be developed is a social order and it is comprehensive. So, every citizen is needed in the creation of this National Security. In short, a whole new cultural model must be immediately brought up in a massive form and easily accepted by every citizen. To answer this challenge, concepts that have been created in the National Sports system should be used. That every Indonesian citizen has a hobby or passion in sports, although of course they are different. Here is the importance of the thesis expressed in the introduction, that each sport model in its ideal form is able to become a combat activity or mode. Especially, sports that use physical agility, although it does not rule out the possibility at all for other types of sports.

\subsection{Civic Fitness as a Basic of Sports Arrangement in National Resilience Perspective}

Law No. 3/2005 issued to maintain and safeguard the Nation, so the Nation certainly requires some kind of backup components and supporting components. These components must also be regulated in a law, since it has to reach the ideal function. The most likely offer in this case is to present a draft of law on managing National Resources to defend the country. Aside from being an offer, actually the draft Act would be used as a strategic material reserve for National Defense. This can be based on the argument that the management of National Resources for National Defense is an effort, or action or activity to transform human resources, natural resources, and artificial resources into a National Defense force that is ready to be used for National Defense. 
Seeing this, the Human Resources and Natural Resources can be said to be the main sources of the National Defense component [10]. If we return to the discussion that has been explained before, the use of existing sports is closely related to these two sources. Especially if it returns to the notion of sport related to the conquest of humans and nature.

Structuring the sports branches into a special regulation that is integrated with the National Defense System, becomes an ideal plan and that is quite interesting, effective and efficient. In the initial step, the structuring undertaken, of course, involves actively athletes who have mastered the sports. This must be done so that the politics of sport campaign can find its way first. That sport was originally a national movement that was not separated from other national movements. Sport was once a media to move the masses, media to encourage the nation, and media to preserve the spirit of mutual cooperation. Socially, the existence of sports clubs is a good example for community empowerment. When the community is incorporated in a sports group, a good, shared spirit emerges. Especially, if the sports club is able to make achievements to the national level. This is also supported by efforts to democratize sports, so that public participation is highly prioritized. The need for community participation is no longer about campaigning for the sports, but also some active roles in promoting sports in their respective regions [11].

The most important step that must be taken in formulating the politics of sport is to spread the belief that sport contains potential seeds to maintain the integrity of the nation. This can be based on the implementation of the Pancasila, including the efforts to keep the body in a good shape, all of these cabs be used as the initial spirit of the Defending the Country. In its extreme form of Defending, the State's efforts in the National Resilience system is the need in war participation. A good citizen will prepare himself to defend his country, like in certain countries, such as China, Korea, and Egypt, the basic form of this effort is a compulsory in military program. This effort far more effective than a comprehensive campaign to Citizens. However, even though Indonesia does not have a Compulsory Military program, Citizens' interest for sports could be began as a good start point. The simplest form is to create new trends in the sports paradigm, including work to incorporate the curriculum of certain sports into school education system. With note, this sports education must be widened by bringing up new variants of sports that are considered by the government.

Juniawan Priyono et al, have important points regarding the conception of Indonesia's National Resilience. Juaniawan et al. Believed that the concept of National Resilience could not be separated from the role of the military and military power. There are at least seven aspects that will influence the concept of National Resilience as a geostrategy, namely: 1) Projection of military power and instruments of war, 2) National objectives, 3) Foreign Policy, 4) Geographical factors, 5) change schemes, 6) Aggressive-offensive character, 7) and geopolitical sub-fields [12]. Clearly, there are no points related to sports in this Priyono et al. However, the conception of National Resilience, indeed, can never be separated from the existence of the military or the methods used by the military. This can easily be understood, because basically all countries in the world use the same method. Therefore, the Defending the Nation campaign will indeed not succeed if it is developed only at the concept level. The development and formation of the character of Defending the Country must involve physical activity.

This would be very likely to be implemented in countries that do have "conscription" schemes. However, for countries that do not require it, such as Indonesia, naturally developing a concept of National Resilience militaristically will pose a problem. But at the same time, "the national needs of its citizens in terms of National Defense" are indeed in this kind of militaristic form. Sports, especially those that are semi-combatants' style, can be made as a very reasonable choice for citizens to possess. Certain sports that are already known to have relations with 
military activities such as martial arts, athletics, and other strenuous sports, of course, are well recognized by goverment. However, the burden that exists for athletes or participants of these strenuous sports is not light. So, it tends to be ineffective because it requires special expertise and determination. Meanwhile, basically the sporting needs that can be used for combat are not necessarily heavy. But it can take other special needs from a battle. Like the ability to throw things, or popular sports that are drawn to the National Resistance campaign.

Meanwhile, sports that are needed to be included in the reserve component of National Defense are sports that fall into the category of unpopular and popular sports. Unpopular sports that actually have the potential for combatants such as javelin throwing, discus throwing, and knife throwing. Meanwhile, popular sports that need to get a touch of new values such as soccer, basketball, sepak takraw, and all types of racing. The skills of all the sports mentioned above will basically be needed by citizens to practice the conception of National Resilience. Regardless of any choice, any type of sport will be able to reach a level worthy of use in battle.

Meanwhile, to get broad attention from citizens, keywords are also needed. One of the possibilities is about Civic fitness or can be interpreted as citizenship fitness. This keyword is able to show that sport is no longer just a physical endeavor for the body, but also a physical for the body and at the same time to build up spiritually. Civic fitness discourse is similar to political fitness discourse, one of which was put forward by John Garrard. Garrard questioned how a citizen could be considered suitable to live in the political climate of a particular country. There are at least three main things that must be answered, first: about the suitability in terms of independence, rationality, political commitment, second: about the extent to which ownership of values and virtues can be done, third: the extent to which the abilities of people can be judged as citizens who are able to exert the influence [13].

In this case, the required sports model has been obtained and so has the initial development model that can be used. The recommendation that can be given to the government as an offer of regulation is to strengthen the position of semi-combatant sports branches as an applicative subject on the idea of National Defense or State Defense. Strengthening needed in the end turned out to be not just one position but must be balanced and sustainable with each other. Wardji Reksohutomo discussed this by incorporating socio-cultural strategies through the Student path. Reksohutomo conveyed about the main abilities that must be well developed, namely in the cognitive aspects, affective aspects, psychomotor aspects. The psychomotor aspect is considered as the culmination of the development needed in conducting National Defense. However, cognitive aspects and affective aspects are two paths that must be taken towards psychomotor. In the end, a human must realize the behavior he is aware of and stable emotions [14].

Awareness about the conception of National Resilience is ultimately the goal of every Indonesian citizen for his country. Thus, a conception that is built will only last when the formation of consciousness has been obtained. Sport in its most basic form is a physical problem which is packaged in the form of a game and given rules. However, then the packaging of this game turned out to be able to give new meaning to human national identity. Something that might not be obtained in the form of games or other activities that might be more important in its basic form. In line with this, the initial view of Scouting also showed a "diminution of values". Nevertheless, the course of history has proven that awareness to do much to the Nation and the State is dominated by Scouts. In the next stage, awareness to defend the country can be approached by forming a State Defending education model that is integrated with citizenship education [15]. This awareness can be started from the formation of sensitivity to the surrounding environment. Scouting and sports are two things that can be used to shape sensitivity to the natural surroundings. The end of this process is the meeting of a concept of 
consciousness that can be used as a confirmation that sport and everything related to physical matters are basically not about duality. However, it is about unity that is able to be formed and developed separately at the same time.

\section{Conclusion}

The concept of a National Resilience System is an effort that must be maintained and introduced to all Citizens. The methods that can be used can vary, so that conditions that can be approached by citizens are also not limited to certain methods. National Defense has so far been as if it were only the domain of the Police and the TNI. This makes the discussion of National Resilience loaded with elements of militarization, the effect of which is that civil society perceives this as something distant. This is certainly not true in full, considering that in an emergency, the state will need help from all elements of society. Even in certain countries, the conscription scheme was indeed used as an initial anticipation and at the same time was an effort to internalize the idea of National Resilience, as was done in Egypt, Singapore, Korea, and China. Indonesia as a country that does not use a conscription scheme, must find ways that can be alternative in terms of efforts to internalize the National Resilience system.

One of the ways that can be used and tends to be effective is through the optimization of the National Sports System. Conceptually, what is recorded in Law No. 3 of 2005 concerning the National Sports System has been quite comprehensive. However, practice in the field, especially in the effort to socialize sports as a basis for National Resilience has not shown significant results. The main problem is lain on the sport that have been seen as an extension of hobbies or recreation. Meanwhile, the idea set by the state into the National Sports system is still not well understood by Citizens. Aside, coaching schemes carried out by the government should be comprehensive and adapted to the needs of the community. While the coaching model that is carried out is more towards the pragmatization of sports, so sports branches that are considered not strategic in terms of championships or achievements are quite rarely received attention. This of course, increasingly makes the public's attention to the sports world increasingly small.

Meanwhile, sports in the international scope have been integrated with the national politics. Major events of sports in the world level, are the stages for world citizens to show their respective national identities. Nationalism is a very close and very easy thing to find in the world sports arena. Even it can be said, sports matches have become a new model of battle amongs nations in a better way. The athletes will be welcomed as soldiers or fighters are entrusted to fight on behalf of the country. Therefore, sports politics should have received a sizable portion of studies in Indonesia. Awareness of the National Identity is very possible to be raised through sports. In addition, better sports management can of course be used as a strategic reserve component of the Republic of Indonesia's National Endurance system.

The remaining problem is about how to bridge the unification effort between the National Resilience System and the National Sports System in accordance with the interests of Citizens. The answer to this problem can certainly be found in the power of good concepts. Something that can be enjoyed easily by all citizens, approximately when a citizen does that, then he feels he has done good for his country in an elegant form. The concept of civic health or civic fitness as an extension of the idea of political fitness can be used as a basic form of this campaign. Core of the concept is that when a citizen carries out sports activities and deepens them and then understands well that the sport can be used to defend the country, citizenship fitness will emerge.

Citizens will have a conception that is healthy and useful for the Nation and the Indonesian State, this will happen when the Citizens have mastered certain types of sports. This view has 
been successfully internalized by many countries. Indonesia also, in terms of its excellent capacity in the midst of the world sports arena, should be able to do a similar or even better internalization model. The greatest assistance to smooth this plan can be obtained through the history of the Indonesian people, local wisdom, and the pride of young people in social activities, say Scouting as an example. So, sports, especially those with semi-combatant potential, should be properly fostered and arranged by the government through existing regulations. Civic fitness ideas are very possible to be used as a standard or basis for this arrangement. In order to achieve an ideal and sufficient nationality for Indonesian citizenship, an integral and comprehensive scheme is needed, both at the conceptual and practical level this work has to be done.

\section{References}

[1] C. U. Press, "https://dictionary.cambridge.org/dictionary/english/sport. [Online]," 2019. .

[2] S. Setiyawan, "Visi Pendidikan Jasmani dan Olahraga," J. Ilm. Penjas, vol. 3, no. 1, 2017.

[3] A. M. Fatwa, Potret Konstitusi Pasca Amandemen UUD 1945. Jakarta: Penerbit Buku Kompas, 2009.

[4] M. Rasyaf, Manajemen Peternakan Ayam Broiler. Jakarta: Penebar Swadaya, 2005.

[5] A. Qoriah, "Nasionalisme Olahraga," J. Media Ilmu Keolahragaan Indones., vol. 5, no. 1, pp. 17, 2015.

[6] A. Bairner, "Sport, nationalism and globalization: Relevance, impact, consequences," Hitotsubashi J. arts Sci., vol. 49, no. 1, pp. 43-53, 2008.

[7] D. Druckman, "Nationalism, patriotism, and group loyalty: A social psychological perspective," Mershon Int. Stud. Rev., vol. 38, no. Supplement_1, pp. 43-68, 1994.

[8] A. A. Putra, "Nilai Adaptif-reflektif Dalam Sindir-kias Sebagai Wujud Dinamika Kebudayaan Bahasa Minangkabau," J. Filsafat, vol. 27, no. 1, pp. 1-29, 2017.

[9] B. Darmono, "Konsep dan Sistem Kamnas Indonesia,” J. Ketahanan Nas., vol. 17, no. 1, pp. 141, 2010.

[10] K. Khotimah, "MEMBANGUN KEKUATAN PERTAHANAN MELALUI PENGELOLAAN ENERGI TERBARUKAN BERBASIS KEARIFAN LOKAL MASYARAKAT," J. Pertahanan Bela Negara, vol. 8, no. 3, 2018.

[11] H. Hadjarati, "Memberdayakan Olah Raga Nasional,” J. Pelangi Ilmu, vol. 2, no. 5, 2009.

[12] J. Priyono, "UJI FALSIFIKASI KONSEPSI KETAHANAN NASIONAL SEBAGAI GEOSTRATEGI INDONESIA,” J. Pertahanan Bela Negara, vol. 7, no. 2, 2017.

[13] J. Garrard, The Political Fitness of Middle-Class Males. In: Democratisation in Britain. London: Palgrave, 2002.

[14] W. Reksohutomo, "Meningkatkan Ketahanan Nasional dalam Bidang Sosial-budaya Lewat Jalur Mahasiswa," Cakrawala Pendidik., 1987.

[15] K. W. Soepandji, "KONSEP BELA NEGARA DALAM PERSPEKTIF KETAHANAN NASIONAL," J. Huk. Pembang., vol. 48, no. 3, pp. 436-456, 2018. 